\title{
Renin-Angiotensin-Aldosterone System Inhibitors in Patients with COVID-19: General Considerations and Clinical Implications
}

Neiberg de Alcantara Lima1,3,* Pedro Yuri Paiva Lima², Ricardo Lessa de Castro Junior ${ }^{1,3}$, Eric Martin Sieloff', Stela Maria Vitorino Sampaio³

ORCID IDS

Lima NA (D) https://orcid.org/ 0000-0003-3616-435X

Lima PYP (D) https://orcid.org/0000-0002-4997-3108

Sieloff EM (D) https://orcid.org/0000-0003-2137-037X

Castro Junior RL (D) https://orcid.org/0000-0002-8153-7998

Sampaio SMV (D) https://orcid.org/0000-0003-1314-2107

\begin{abstract}
Initially reported in China at the end of 2019, the coronavirus pandemic has now reached an international scale with more than 1.5 million cases worldwide and more than 80,000 deaths by April $8^{\text {th }}$ of this year. Recent studies have shown that the virus invades host cells by the angiotensin-converting enzyme 2 receptor, making it essential to viral transmission. Concerns have been raised about possible benefits and harms associated with the use of angiotensin-converting enzyme (ACE) inhibitors and angiotensin receptors blockers in these patients. However, there is lack of evidence to recommend even temporarily discontinuing reninangiotensin system inhibitors/blockers in patients infected with the SARS-CoV-2.
\end{abstract}

KEYWORDS: Coronavirus; Pandemics; Renin-angiotensin system; Angiotensin-converting enzyme inhibitors; COVID-19.

1.Western Michigan University Homer Stryker - School of Medicine - Internal Medicine - Kalamazoo (MI), USA.

2.McGill University - Department of Cardiology - Montreal, Canada.

3. Hospital de Messejana - Departamento de Cardiologia - Fortaleza (CE), Brasil.

*Correspondence author: neiberg.lima@med.wmich.edu

Received: 09 Apr 2020 | Accepted: 09 Apr 2020 


\section{INTRODUCTION}

Initially reported in China at the end of 2019, the coronavirus pandemic has now reached an international scale with more than 1.5 million cases worldwide and more than 80,000 deaths by April $8^{\text {th }}$ of this year ${ }^{1}$. Most patients who end up in the intensive care unit (ICU) have significant lung deterioration and require mechanical ventilation. However, cardiac complications including myocardial ischemia, myocarditis and cardiac dysfunction have also been described and can substantially increase the mortality rate ${ }^{2}$.

Recent studies showed that COVID-19 virus invades host cells by the angiotensin-converting enzyme 2 (ACE2) receptor, making it essential to viral transmission ${ }^{3}$. The virus uses the ACE2 receptor, downregulating the reninangiotensin-aldosterone system (RAS) and thus, the modulation of this process could have implications in disease progression ${ }^{4}$.

\section{COVID-19, SARS and ACE2}

ACE2 is present in multiple organs and is directly associated with heart function and the development of diabetes and hypertension ${ }^{5}$. As is known from classic previous studies, ACE inhibitors (ACEIs) have an important role in the treatment of cardiovascular disease, significantly reducing morbidity and mortality in patients with heart failure ${ }^{6-9}$, for which the same is seen with the use of renin-angiotensin system (RAS) antagonist medications ${ }^{10,11}$.

Because of this association of COVID-19 with the ACE2 receptor, there are concerns of possible benefits and harms associated with the use of ACE inhibitors and angiotensin receptors blockers (ARBs) in infected patients.

Since the first outbreak of SARS-related coronavirus in 2003, the ACE2 protein was known as a receptor for the SARS-CoV virus ${ }^{12}$. Due to this association, when scientists initially isolated the new virus (SARS-CoV-2) and published the genome sequence collected from the first five patients in Wuhan, China, the hypothesis of ACE2 being a cellular entry receptor was formulated. The results confirmed that only cells expressing ACE2 receptor could be infected ${ }^{13}$. Given this mechanism, a concern about the use of RAS antagonists, which can potentially increase the expression of ACE2 leading to an increased virus infection, was raised in the medical community. The correlation between elevated plasma levels of ACE2 and the severity of lung injury in COVID-19 infected patients ${ }^{14}$ also corroborated this concern. Despite the existence of a feasible and plausible mechanism, there is no evidence to support this potential effect in humans. Many studies have investigated elevated ACE2 levels in patients with cardiovascular diseases including poor biventricular performance ${ }^{15}$, left atrium remodeling ${ }^{16}$ and myocardial fibrosis among patients with severe aortic stenosis ${ }^{17}$, yet, none were able to demonstrate that ACEI/ARB use had any influence. Only one study assessed the long-term effect of ACEIs/ARBs on the treatment of patients with hypertension: Olmesartan is the only drug found to have an increased ACE2 level in the urine ${ }^{18}$.

All this data was produced using animal experiments, preclinical observation studies and trials of patients not infected with the new SARS-CoV-2. Nearly four months after the first cases described in December 2019, and the worldwide spread of the virus, initial retrospective cohorts show a high prevalence of hypertension from $13 \%$ in nonsevere patients ${ }^{19}$ up to $30 \%$ among hospitalized patients ${ }^{20,21}$. Based on this, a considerable number of patients are expected to be taking ACEIs and ARBs. Meng and colleagues retrospectively analyzed 42 patients (17 of them on ACEIs or ARBs) admitted to a single center in China for which both groups had an equal number of severe disease presentations and baseline characteristics. Considering the limitations of a small retrospective analysis, the RAS group had better clinical and laboratorial outcomes than the non-RAS group ${ }^{13}$. Another retrospective analysis of 112 patients with SARS-CoV-2 performed in Wuhan found that the use of ACEIs or ARBs had no effect on mortality and morbidity ${ }^{22}$. These findings reinforce the idea presented by Liu et al. who proposed that in patients infected with the COVID-19, angiotensin II plasma levels are directly correlated with viral load and lung injury - suggesting the use of ARBs as a potential treatment for these patients ${ }^{14}$. 


\section{ACEIs/ARBs and GUIDELINES}

ACEIs and ARBs have been widely used worldwide for decades. Their benefits in heart disease, hypertension and kidney disease are well known.

ACEIs have shown decreasing mortality, morbidity and hospitalizations regardless of the etiology and severity of the heart failure with reduced ejection fraction (HFrEF) ${ }^{23,24}$. The American Heart Association (AHA), American College of Cardiology (ACC), European Society of Cardiology (ESC) and Brazilian Society of Cardiology (SBC) recommend ACEIs for all patients with HFrEF unless contraindicated ${ }^{25-27}$. ACEIs should be started as soon as the patient is diagnosed with HFrEF and should not be discontinued even if left ventricle function improves ${ }^{28}$. Therefore, in times of pandemic, when access to the healthcare system is limited, changing ACEI long term treatment is risky and can be fatal in patients with HFrEF.

ACEIs and ARBs are the most frequently used medications for hypertension (HTN), especially in patients with diabetes, microalbuminuria and heart disease. ACC/AHA, ESC and SBC recommend their use as a first line medication - independently, or combined with diuretics and/or calcium channel blockers ${ }^{29-31}$. Even for patients with hypertension without target organ damage, the regimen change is possible but still requires strict outpatient follow up. At this point, when the number of COVID-19 cases continues to increase and the demand of certified healthcare professionals and medical supplies rises, avoiding unnecessary visits is mandatory in order to reduce possible virus exposures and to further avoid overwhelming the health system.

ACEIs and ARBs are also indicated for patients with chronic kidney disease with or without diabetes in the presence of elevated urinary albumin excretion ${ }^{32}$. The risk of temporarily discontinuing these medications in this population could appear low in the short term; however, as far as is known, there are no studies to validate this suspicion.

Despite current experimental studies showing the potential of ACEIs increasing the risks of complicated SARS-Cov-2, there are no robust human studies validating this harm to date (April $8^{\text {th }}$ of 2020). Furthermore, the dangers of discontinuing ACEIs on large scale could be tremendous. A recent AHA/ACC statement advises against discontinuing $\mathrm{ACEI} / \mathrm{ARB}$ in patients with COVID-19 unless there is a separate contraindication. A statement by the $\mathrm{SBC}$ recommends individually evaluating the cardiovascular risks of discontinuing these medications in patients with COVID-19.

\section{CONCLUSION}

In summary, based on the evidence presented by current studies up until April $8^{\text {th }}$ of 2020, there is lack of evidence to recommend even temporarily discontinuing RAS antagonists in patients infected with the SARS-CoV-2 as well as to prescribe them for all patients. The use of this class of drugs as potential treatment to modulate plasma ACE2 levels is not yet clearly elucidated and requires further clinical trials for before such conclusions can be made.

\section{REFERENCES}

1. Dong E, Du H, Gardner L. An interactive web-based dashboard to track COVID-19 in real time. Lancet Infect Dis. 2020;20(5):533-4. https://doi.org/10.1016/S1473-3099(20)30120-1

2. Clerkin KJ, Fried JA, Raikhelkar J, Sayer G, Griffin JM, Masoumi A, et al. COVID-19 and cardiovascular disease. Circulation. 2020;141(20):1648-55. https://doi.org/10.1161/CIRCULATIONAHA.120.046941

3. Hoffmann M, Kleine-Weber H, Schroeder S, Krüger N, Herrler T, Erichsen S, et al. SARS-CoV-2 Cell entry depends on ACE2 and TMPRSS2 and is blocked by a clinically proven protease inhibitor. Cell. 2020;181(2):271-80. https://doi.org/10.1016/j.cell.2020.02.052

4. Madjid M, Safavi-Naeini P, Solomon SD, Vardeny O. Potential effects of coronaviruses on the cardiovascular system: A review. JAMA Cardiol. Published online March 27, 2020. https://doi.org/10.1001/jamacardio.2020.1286 
5. Zheng Y-Y, Ma Y-T, Zhang J-Y, Xie X. COVID-19 and the cardiovascular system. Nat Rev Cardiol. 2020;17(5):256-60. https://doi. org/10.1038/s41569-020-0360-5

6. Cohn JN, Johnson G, Ziesche S, Cobb F, Francis GS, Tristani F, et al. A comparison of enalapril with hydralazine-isosorbide dinitrate in the treatment of chronic congestive heart failure. N EngIJ Med. 1991;325(5):303-10. https://doi.org/10.1056/NEJM199108013250502

7. The Consensus Trial Study Group. Effects of enalapril on mortality in severe congestive heart failure: results of the cooperative North Scandinavian enalapril survival study (CONSENSUS). N Engl J Med. 1987;316(23):1429-35. https://doi.org/10.1056/ NEJM198706043162301

8. The SOLVD Investigators. Effect of enalapril on survival in patients with reduced left ventricular ejection fractions and congestive heart failure. N Engl J Med. 1991;325(5):293-302. https://doi.org/10.1056/NEJM199108013250501

9. The SOLVD Investigators. Effect of enalapril on mortality and the development of heart failure in asymptomatic patients with reduced left ventricular ejection fractions. N Engl J Med. 1992;327(10):685-91. https://doi.org/10.1056/NEJM199209033271003

10. Pitt B, Zannad F, Remme WJ, Cody R, Castaigne A, Perez A, et al. The effect of spironolactone on morbidity and mortality in patients with severe heart failure. N Engl J Med. 1999;341(10):709-17. https://doi.org/10.1056/NEJM199909023411001

11. Pitt B, Remme WJ, Zannad F, Neaton J, Martinez F, Roniker B, et al. Eplerenone, a selective aldosterone blocker, in patients with left ventricular dysfunction after myocardial infarction. N Engl J Med. 2003;348(14):1309-21. https://doi.org/10.1056/NEJMoa030207

12. Kuhn JH, Li W, Choe H, Farzan M. What's new in the renin-angiotensin system? Angiotensin-converting enzyme 2: a functional receptor for SARS coronavirus. CMLS, Cell Mol Life Sci. 2004;61(21):2738-43. https://doi.org/10.1007/s00018-004-4242-5

13. Meng J, Xiao G, Zhang J, He X, Ou M, Bi J, et al. Renin-angiotensin system inhibitors improve the clinical outcomes of COVID-19 patients with hypertension. Emerg Microbes Infect. 2020;9(1):757-60. https://doi.org/10.1080/22221751.2020.1746200

14. Liu Y, Yang Y, Zhang C, Huang F, Wang F, Yuan J, et al. Clinical and biochemical indexes from 2019-nCoV infected patients linked to viral loads and lung injury. Sci China Life Sci. 2020;63(3):364-74. https://doi.org/10.1007/s11427-020-1643-8

15. Epelman S, Shrestha K, Troughton RW, Francis GS, Sen S, Klein AL, et al. Soluble angiotensin-converting enzyme 2 in human heart failure: relation with myocardial function and clinical outcomes. J Card Fail. 2009;15(7):565-71. https://doi.org/10.1016/j. cardfail.2009.01.014

16. Walters TE, Kalman JM, Patel SK, Mearns M, Velkoska E, Burrell LM. Angiotensin converting enzyme 2 activity and human atrial fibrillation: increased plasma angiotensin converting enzyme 2 activity is associated with atrial fibrillation and more advanced left atrial structural remodelling. EP Europace. 2017;19(8):1280-7. https://doi.org/10.1093/europace/euw246

17. Ramchand J, Patel SK, Kearney LG, Matalanis G, Farouque O, Srivastava PM, et al. Plasma ACE2 activity predicts mortality in aortic stenosis and is associated with severe myocardial fibrosis. JACC Cardiovasc Imaging. 2020;13(3):655-64. https://doi.org/10.1016/j. jcmg.2019.09.005

18. Furuhashi M, Moniwa N, Mita T, Fuseya T, Ishimura S, Ohno K, et al. Urinary angiotensin-converting enzyme 2 in hypertensive patients may be increased by olmesartan, an angiotensin II receptor blocker. Am J Hypertens. 2015;28(1):15-21. https://doi. org/10.1093/ajh/hpu086

19. Guan W-J, Ni Z-Y, Hu Y, Liang W-H, Ou C-Q, He J-X, et al. Clinical characteristics of coronavirus disease 2019 in China. N Engl J Med. 2020;382(18):1708-20. https://doi.org/10.1056/NEJMoa2002032

20. Wu C, Chen X, Cai Y, Xia J, Zhou X, Xu S, et al. Risk factors associated with acute respiratory distress syndrome and death in patients with coronavirus disease 2019 pneumonia in Wuhan, China. JAMA Intern Med. Published online March 13, 2020. https:// doi.org/10.1001/jamainternmed.2020.0994

21. Zhou F, Yu T, Du R, Fan G, Liu Y, Liu Z, et al. Clinical course and risk factors for mortality of adult inpatients with COVID-19 in Wuhan, China: a retrospective cohort study. Lancet. 2020;395(10229):1054-62. https://doi.org/10.1016/S0140-6736(20)30566-3

22. Peng YD, Meng K, Guan HQ, Leng L, Zhu RR, Wang BY, et al. Clinical characteristics and outcomes of 112 cardiovascular disease patients infected by 2019-nCoV. Chin J Cardiol. 2020;48:E004. https://doi.org/10.3760/cma.j.cn112148-20200220-00105

23. Helmrich SP, Ragland DR, Leung RW, Paffenbarger Junior RS. Physical activity and reduced occurrence of non-insulin-dependent diabetes mellitus. N Engl J Med. 1991;325(3):147-52. https://doi.org/10.1056/NEJM199107183250302

24. Pfeffer MA, Braunwald E, Moyé LA, Basta L, Brown Junior EJ, Cuddy TE, et al. Effect of captopril on mortality and morbidity in patients with left ventricular dysfunction after myocardial infarction — results of the survival and ventricular enlargement trial. N Engl J Med. 1992;327(10):669-77. https://doi.org/10.1056/NEJM199209033271001 
25. Yancy CW, Jessup M, Bozkurt B, Butler J, Casey Junior DE, Drazner MH, et al. 2013 ACCF/AHA guideline for the management of heart failure: A report of the American College of Cardiology Foundation/American Heart Association Task Force on Practice Guidelines. J Am Coll Cardiol. 2013;62(16):e147-239. https://doi.org/10.1161/CIR.0b013e31829e8776

26. Ponikowski P, Voors AA, Anker SD, Bueno H, Cleland JGF, Coats AJS, et al. 2016 ESC Guidelines for the diagnosis and treatment of acute and chronic heart failure: The Task Force for the diagnosis and treatment of acute and chronic heart failure of the European Society of Cardiology (ESC) Developed with the special contribution of the Heart Failure Association (HFA) of the ESC. Eur Heart J. 2016;37(27):2129-200. Erratum for: Eur Heart J. 2018;39(14):1206. https://doi.org/10.1093/eurheartj/ehx158

27. Comitê Coordenador da Diretriz de Insuficiência Cardíaca. Diretriz Brasileira de Insuficiência Cardíaca Crônica e Aguda. Arq Bras Cardiol. 2018;111(3):436-539.

28. Halliday BP, Wassall R, Lota AS, Khalique Z, Gregson J, Newsome S, et al. Withdrawal of pharmacological treatment for heart failure in patients with recovered dilated cardiomyopathy (TRED-HF): an open-label, pilot, randomised trial. Lancet. 2019;393(10166):61-73. https://doi.org/10.1016/S0140-6736(18)32484-X

29. Whelton PK, Carey RM, Aronow WS, Casey DE Jr, Collins KJ, Dennison Himmelfarb C, et al. 2017 ACC/AHA/AAPA/ABC/ACPM/AGS/ APhA/ASH/ASPC/NMA/PCNA guideline for the prevention, detection, evaluation, and management of high blood pressure in adults: a report of the American College of Cardiology/American Heart Association Task Force on Clinical Practice Guidelines. Hypertension. 2018;71:e13-115. https://doi.org/10.1161/HYP.0000000000000065

30. Williams B, Mancia G, Spiering W, Rosei EA, Azizi M, Burnier M, et al. 2018 ESC/ESH guidelines for the management of arterial hypertension: The task force for the management of arterial hypertension of the European Society of Cardiology (ESC) and the European Society of Hypertension (ESH). Eur Heart J. 2018;39(33):3021-104. Erratum for: Eur Heart J. 2019;40(5):475. https://doi. org/10.1093/eurheartj/ehy686

31. Malachias MVB, Souza WKSB, Plavnik FL, Rodrigues CIS, Brandão AA, Neves MFT, et al. $7^{\text {a }}$ Diretriz Brasileira de Hipertensão Arterial. Arq Bras Cardiol. 2016;107(3):1-83.

32. Corbo JM, Delellis TM, Hill LG, Rindfuss SL, Nashelsky J. ACE Inhibitors or ARBs to prevent CKD in patients with microalbuminuria. Am Fam Physician. 2016;94(8):652-3. 